\title{
KINETICS AND MECHANISM OF THE AQUEOUS PHASE OXIDATION OF HYDROGEN SULFIDE BY OXYGEN: CATALYZED BY HYDROQUINONE
}

\author{
Deepak Singh Rathore and C. P. Singh Chandel \\ Atmospheric Chemistry Laboratory, Department of Chemistry, \\ University of Rajasthan, Jaipur-302004, (Rajasthan) India \\ *E-mail: chandelcps2@ rediffmail.com
}

\begin{abstract}
Hydroquinone, which is a trace atmospheric constituent, catalyzes the oxidation of hydrogen sulfide in aqueous phase strongly. The reaction was followed by measuring the disappearance of oxygen with the help of DO meter in a reactor. The reaction obeys the kinetics rate law:

$-\mathrm{d}\left[\mathrm{O}_{2}\right] / \mathrm{dt}=\mathrm{k}_{2} \mathrm{~K}_{1} \mathrm{~K}_{3} \mathrm{~K}_{4}\left[\mathrm{M}^{\mathrm{n}+}\right]\left[\mathrm{O}_{2}\right]\left[\mathrm{H}_{2} \mathrm{Q}\right][\mathrm{S}]\left[\mathrm{H}^{+}\right] /\left\{\left[\mathrm{H}^{+}\right]^{2}+\mathrm{K}_{1}\left[\mathrm{H}^{+}\right]+\mathrm{K}_{1} \mathrm{~K}_{2}\right\}$

This work shows hydroquinone to be a strong catalyst for the oxidation of $\mathrm{H}_{2} \mathrm{~S}$ by $\mathrm{O}_{2}$ and therefore it will catalyze the oxidation of aqueous $\mathrm{H}_{2} \mathrm{~S}$ into $\mathrm{H}_{2} \mathrm{SO}_{4}$ and contribute the acidification of atmospheric water.

Keywords: Hydrogen sulfide, Hydroquinone, Oxygen, Oxidation, Catalysis.
\end{abstract}

(c) RASĀYAN. All rights reserved

\section{INTRODUCTION}

Hydroquinone is an important organic compound and has several applications as an antioxidant in industry. Production and applications of hydroquinone $\left(\mathrm{H}_{2} \mathrm{Q}\right)$ in the industry are its major atmospheric sources. Its use in photographic processes and coal gasification results in its releasing effluents. ${ }^{1-2}$ It is a toxic and hazardous chemical. Its inhalation may cause cyanosis, vomiting, nausea, headache, convulsions, dizziness etc. Hydroquinone causes skin irritation in humans.

The oxidation of hydroquinone $\left(\mathrm{H}_{2} \mathrm{Q}\right)$ by oxygen is well known and has been the subject of several studies and its chemistry is well documented due to its many biological, chemical and clinical functions. It works as an electron transfer reagent in the systems. Quinone chemistry has been the subject of several books ${ }^{3-6}$ and many excellent reviews. ${ }^{7-13}$ The role of different metals in catalyzing the reactions of hydroquinone with oxygen is well known. ${ }^{14}$ Transition metal ion catalysis by overcomes the spin restriction and lowers the free energy of activation. The metal ions favor the formation of a ternary complex- metal -reductantoxygen. The ternary metal $-\mathrm{O}_{2}-\mathrm{H}_{2} \mathrm{Q}$ complex provides several alternative pathways for the reduction of oxygen by hydroquinones. ${ }^{15}$

The $\mathrm{H}_{2} \mathrm{Q}-\mathrm{O}_{2}$ reaction generates intermediates such as superoxide ion, $\mathrm{O}_{2}{ }^{-}$, hydrogen peroxide, etc. The reaction in the absence of metal catalyst is proposed to occur as follows. ${ }^{14}$

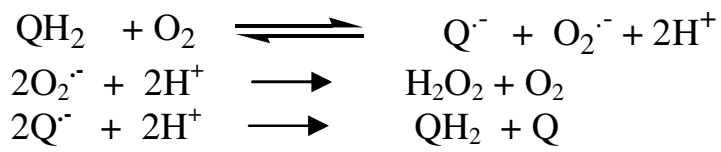

Metal catalyzed oxidation may proceed by the following pathway.

\section{Initiation}

$\mathrm{QH}_{2}+\mathrm{M}^{\mathrm{n}+} \rightleftharpoons \mathrm{Q}^{--}+\mathrm{M}^{(\mathrm{n}-1)+}+2 \mathrm{H}^{+}$

Propagation

$\mathrm{Q}^{-}+\mathrm{O}_{2}$

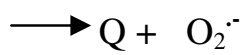

Rasayan J. Chem., 13(1), 112-120(2020)

http://dx.doi.org/10.31788/RJC.2020.1315612 
RASĀYAN J. Chem.

Vol. 13 | No. 1 |112 - 120| January - March | 2020

$\begin{array}{ll}\mathrm{M}^{(\mathrm{n}-1)+}+2 \mathrm{H}^{+}+\mathrm{O}_{2}^{--} & \longrightarrow \mathrm{M}^{\mathrm{n}+}+\mathrm{H}_{2} \mathrm{O}_{2} \\ \mathrm{QH}_{2}+\mathrm{O}_{2}^{--} & \longrightarrow \mathrm{Q}^{--}+\mathrm{H}_{2} \mathrm{O}_{2} \\ \mathrm{QH}_{2}+\mathrm{H}_{2} \mathrm{O}_{2} & \longrightarrow \mathrm{Q}^{--}+\mathrm{OH}^{-}+\mathrm{OH}^{-}\end{array}$

The accumulation of quinone products leads to the propagation reaction of quinone with oxygen by coproportionation.

$\begin{array}{ll}\mathrm{QH}_{2}+\mathrm{Q} & \longrightarrow 2 \mathrm{Q}^{-*}+2 \mathrm{H}^{+} \\ \mathrm{Q}^{-}+\mathrm{O}_{2} & \longrightarrow \mathrm{Q}+\mathrm{O}_{2}^{-*^{-}}\end{array}$

The hydroquinone and the metal catalysts decide the contribution of each of the pathways(4-10). Metalbinding ligands and radical and scavengers also influence these contributions. ${ }^{14}$

The aqueous phase atmospheric oxidation of $\mathrm{H}_{2} \mathrm{~S}$ by oxygen is an important acid rain formation in the atmosphere. $\mathrm{H}_{2} \mathrm{~S}$ is reported to be oxidized by active oxygen species such as $\mathrm{H}_{2} \mathrm{O}_{2}, \mathrm{O}_{2}{ }^{-}, \mathrm{OH}^{\cdot}{ }^{16-17}$ The effect of some VOCs on $\mathrm{H}_{2} \mathrm{~S}$ autoxidation has been studied and while examining the effect of hydroquinone it was found to catalyze the $\mathrm{H}_{2} \mathrm{~S}$ autoxidation. ${ }^{18}$ Since both $\mathrm{H}_{2} \mathrm{~S}$ and $\mathrm{H}_{2} \mathrm{Q}$ are oxidized by $\mathrm{O}_{2}, \mathrm{H}_{2} \mathrm{Q}$ is most likely intervenes in the oxidation of $\mathrm{H}_{2} \mathrm{~S}$ and accelerate the $\mathrm{H}_{2} \mathrm{~S}$ reaction. This led us to investigate the role of hydroquinone, which is found in the atmosphere in trace amount, in aqueous phase oxidation of $\mathrm{H}_{2} \mathrm{~S}$ by $\mathrm{O}_{2}$ in presence of catalytic concentrations of $\mathrm{H}_{2} \mathrm{Q}\left(2 \times 10^{-6}-1 \times 10^{-5} \mathrm{~mol} \mathrm{~L}^{-1}\right)$.

\section{EXPERIMENTAL}

Hydroquinone was of SISCO(98\%) make. In this study, the chemicals of only reagent grade were used. The solutions of these chemicals were prepared always in double-distilled water. The only afresh aqueous solution of sodium sulfide was used. $\mathrm{H}_{2} \mathrm{Q}-\mathrm{H}_{2} \mathrm{~S}-\mathrm{O}_{2}$ reactions were carried out in an air-tight sealed vessel. It was a three-necked glass reactor of $250 \mathrm{ml}$ capacity. It was immersed in a thermo-stated water bath, which was maintained at $30 \pm 0.1{ }^{\circ} \mathrm{C}$. One neck was used for fitting the dissolved oxygen probe. Through the other neck, the oxygen was passed from an $\mathrm{O}_{2}$-cylinder. Sodium sulfide solution was added through the third neck. The following procedure was used for studying kinetics. To begin with, $\mathrm{O}_{2}$ was bubbled in the reactor until the achievement of desired $\left[\mathrm{O}_{2}\right]$. Now the desired amount of aqueous solution of $\mathrm{H}_{2} \mathrm{Q}$ was added followed by the addition of $\mathrm{Na}_{2} \mathrm{~S}$ solution. The reactor was now sealed and the measurement started. The kinetics was followed by recording a decrease in $\mathrm{O}_{2}$ concentration by dissolved oxygen(DO) meter. ${ }^{19}$ To check the reproducibility of the kinetics runs, each experiment was performed at least three times. Such replicate rate determinations were found to be reproducible within $\pm 10 \%$. MS Excel 2007 software was used for all calculations.

\section{Preliminary Investigation}

\section{RESULTS AND DISCUSSION}

Kinetics was studied under pseudo-first-order conditions. The oxygen concentration was in deficit. The concentration of sulfide was in excess at least ten times over oxygen concentration. The catalytic amounts of $\mathrm{H}_{2} \mathrm{Q}$ were used in the range $1 \times 10^{-6}-1 \times 10^{-5} \mathrm{~mol} \mathrm{~L}^{-1}$. Sodium sulfide, $\mathrm{Na}_{2} \mathrm{~S}$ has been used as a source of $\mathrm{H}_{2} \mathrm{~S}$. Hereafter the analytical concentration of $\mathrm{H}_{2} \mathrm{~S}$ has been denoted by [S]. The rate of reaction was measured by following the disappearance of $\left[\mathrm{O}_{2}\right]$. The oxidation of both $\mathrm{H}_{2} \mathrm{~S}$ and $\mathrm{H}_{2} \mathrm{Q}$ is strongly affected by trace metal ion and hence a buffered was not used to avoid the introduction of trace metal impurities present in buffered reagents. In many previous studies, buffers have not used for this reason ${ }^{20}$. Since the buffered was not used, the $\mathrm{pH}$ of the reaction mixture varied slightly with the progress of the reaction.

The reaction obeyed first order kinetics in $\left[\mathrm{O}_{2}\right]$ disappearance both in presence and absence $\mathrm{H}_{2} \mathrm{Q}$ as shown in some representative first-order plots are in Fig.-1. Values of pseudo first-order rate constants, $\mathrm{k}_{\mathrm{obs}}$, were obtained from $\log \left[\mathrm{O}_{2}\right]_{\mathrm{t}}$ versus time, $\mathrm{t}$, plots defined by Eq.(11).

$-\mathrm{d}\left[\mathrm{O}_{2}\right] / \mathrm{dt}=\mathrm{k}_{\mathrm{obs}}\left[\mathrm{O}_{2}\right]_{\mathrm{t}}$

Where $\left[\mathrm{O}_{2}\right]_{\mathrm{t}}$ is the concentration of oxygen at time $\mathrm{t}$.

OXIDATION OF HYDROGEN SULFIDE 


\section{Kinetics in Uncatalyzed Reaction}

At first, the rate law was determined for the uncatalyzed reaction in the absence of $\mathrm{H}_{2} \mathrm{Q}$. The effect of $\mathrm{H}_{2} \mathrm{~S}$ concentration was studied by varying $\mathrm{Na}_{2} \mathrm{~S}\left(2 \times 10^{-3}-8 \times 10^{-3} \mathrm{~mol} \mathrm{~L}^{-1}\right)$ in the unbuffered medium. Kinetics order in $[\mathrm{S}]$ was determined from the plot of $\log \mathrm{k}_{\mathrm{obs}}$ versus $\log [\mathrm{S}]$ and found to be $0.97 \pm 0.14$, which can be taken as unity. Thus, the rate law for the uncatalyzed reaction at a fixed $\mathrm{pH}$ in the absence of hydroquinone is:

$-\mathrm{d}\left[\mathrm{O}_{2}\right] / \mathrm{dt}=\mathrm{k}[\mathrm{S}]\left[\mathrm{O}_{2}\right]_{\mathrm{t}}$

A comparison of Eqs. (11) and (12) shows

$\mathrm{k}_{\mathrm{obs}}=\mathrm{k}[\mathrm{S}]$

In accordance with Eq. (13), the plot of $\mathrm{k}_{\mathrm{obs}}$ versus [S] is linear(Fig.-2). The values of $\mathrm{k}_{\text {obs }}$ at different [S] and $\left[\mathrm{O}_{2}\right]$ are in Table-1.

Table-1: The Selected Values of Rate Constants, $\mathrm{k}_{\mathrm{obs}}$ at Different $[\mathrm{S}]$, mol L $\mathrm{L}^{-1}$ and $\mathrm{t}=30^{\circ} \mathrm{C}$

\begin{tabular}{c|c|c|c}
\hline Initial $\mathrm{pH}$ & {$\left[\mathrm{O}_{2}\right], \mathrm{mg} / \mathrm{L}$} & {$[\mathrm{S}], \mathrm{mol} \mathrm{L}^{-1}$} & $\mathrm{k}_{\mathrm{obs}}, \mathrm{s}^{-1}$ \\
\hline 10.77 & 5.71 & $2 \times 10^{-3}$ & $1.09 \times 10^{-4}$ \\
\hline 11.06 & 5.60 & $4 \times 10^{-3}$ & $2.74 \times 10^{-4}$ \\
\hline 11.23 & 5.70 & $6 \times 10^{-3}$ & $3.22 \times 10^{-4}$ \\
\hline 11.32 & 5.67 & $8 \times 10^{-3}$ & $4.37 \times 10^{-4}$ \\
\hline
\end{tabular}

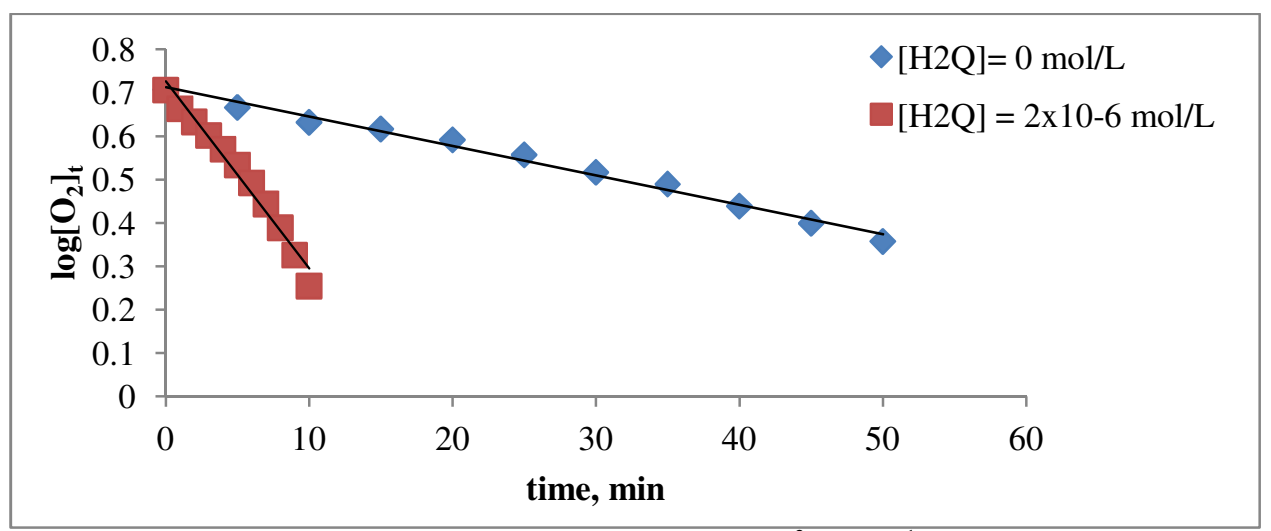

Fig.-1: The Plot of $\log \left[\mathrm{O}_{2}\right]_{\mathrm{t}}$ Versus Time at $[\mathrm{S}]=2 \times 10^{-3} \mathrm{~mol} \mathrm{~L}^{-1}, \mathrm{pH}=10.84$ and $\mathrm{t}=30^{\circ} \mathrm{C}$

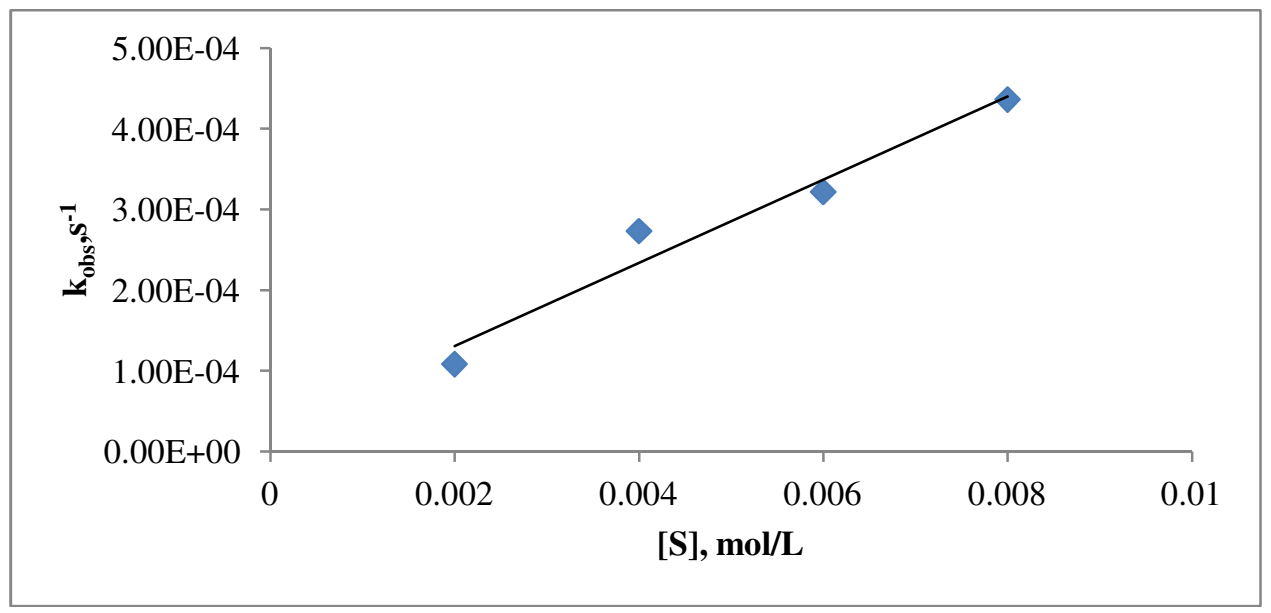

Fig.-2: The Plots of $\mathrm{k}_{\text {obs }}$ Versus $[\mathrm{S}]$ at $\mathrm{pH}=10.77-11.32$ and $\mathrm{t}=30^{\circ} \mathrm{C}$ 


\section{Kinetics of Hydroquinone Catalyzed Reaction}

The effect of $\mathrm{H}_{2} \mathrm{~S}$ concentration in the presence of $\mathrm{H}_{2} \mathrm{Q}$ (Table-2) was studied by varying $\mathrm{Na}_{2} \mathrm{~S}\left(1 \times 10^{-3}\right.$ $\left.9 \times 10^{-3} \mathrm{~mol} \mathrm{~L}^{-1}\right)$. Kinetics order in [S] was determined from the plot of $\log \mathrm{k}_{\mathrm{H} 2 \mathrm{Q}}$ versus $\log [\mathrm{S}]$ and found to be $0.84 \pm 0.1$, which can be taken as unity. The rate law for the catalyzed reaction at a fixed $\mathrm{pH}$ in the presence of hydroquinone is:

$-\mathrm{d}\left[\mathrm{O}_{2}\right] / \mathrm{dt}=\mathrm{k}_{\mathrm{H} 2 \mathrm{Q}}\left[\mathrm{O}_{2}\right]_{\mathrm{t}}$

The effect of $\left[\mathrm{H}_{2} \mathrm{Q}\right]$ at a fixed $\mathrm{pH}$ was found to be governed by the rate law (15).

$\mathrm{k}_{\mathrm{H} 2 \mathrm{Q}}=\mathrm{k}[\mathrm{S}]+\mathrm{k}_{\mathrm{cat}}[\mathrm{S}]\left[\mathrm{H}_{2} \mathrm{Q}\right]$

Where, $\mathrm{k}_{\text {cat }}$ is rate constant for $\mathrm{H}_{2} \mathrm{Q}$-catalyzed reaction.

Table-2: The Selected Value of $\mathrm{k}_{\mathrm{H} 2 \mathrm{Q}}$ at $\left[\mathrm{H}_{2} \mathrm{Q}\right]=3 \times 10^{-6} \mathrm{~mol} \mathrm{~L}^{-1}$ and $\mathrm{t}=30^{\circ} \mathrm{C}$

\begin{tabular}{c|c|c|c|c}
\hline $\begin{array}{c}{\left[\mathrm{O}_{2}\right],} \\
\mathrm{mg} / \mathrm{L}\end{array}$ & $\mathrm{pH}$ & $\begin{array}{c}\text { [Hydroquinone }], \\
\mathrm{mol} \mathrm{L}^{-1}\end{array}$ & {$[\mathrm{~S}], \mathrm{mol} \mathrm{L}^{-1}$} & $\mathrm{k}_{\mathrm{H} 2 \mathrm{Q}}, \mathrm{s}^{-1}$ \\
\hline 5.11 & 10.13 & $3 \times 10^{-6}$ & $1 \times 10^{-3}$ & $5.79 \times 10^{-4}$ \\
\hline 4.86 & 10.67 & $3 \times 10^{-6}$ & $2 \times 10^{-3}$ & $1.42 \times 10^{-3}$ \\
\hline 4.82 & 10.97 & $3 \times 10^{-6}$ & $3 \times 10^{-3}$ & $2.14 \times 10^{-3}$ \\
\hline 4.79 & 11.11 & $3 \times 10^{-6}$ & $4 \times 10^{-3}$ & $2.45 \times 10^{-3}$ \\
\hline 4.91 & 11.21 & $3 \times 10^{-6}$ & $7 \times 10^{-3}$ & $3.23 \times 10^{-3}$ \\
\hline 4.82 & 11.30 & $3 \times 10^{-6}$ & $9 \times 10^{-3}$ & $4.14 \times 10^{-3}$ \\
\hline
\end{tabular}

The variation of $\mathrm{k}_{\mathrm{H} 2 \mathrm{Q}}$ was first order in $[\mathrm{S}]\left(\right.$ Fig.-3). The plot of $\mathrm{k}_{\mathrm{H} 2 \mathrm{Q}}$ versus $\left[\mathrm{H}_{2} \mathrm{Q}\right]$, mol L $\mathrm{L}^{-1}$ was linear as shown in Fig. 4 . The values of $\mathrm{k}_{\mathrm{H} 2 \mathrm{Q}}$ at different $\left[\mathrm{H}_{2} \mathrm{Q}\right]$ and $\left[\mathrm{O}_{2}\right]$ in the presence of $[\mathrm{S}]=2 \times 10^{-3} \mathrm{~mol} \mathrm{~L}^{-1}$ are in Table-3. The value of intercept $(=\mathrm{k}[\mathrm{S}])$ and the slope $\left(=\mathrm{k}_{\mathrm{cat}}[\mathrm{S}]\right)$ were found to be $4.74 \times 10^{-4}$ and $4.3 \times 10^{2}$ \pm 30 respectively at $[\mathrm{S}]=2 \times 10^{-3} \mathrm{~mol} \mathrm{~L}^{-1}, \mathrm{pH}=\sim 10.8$ and $\mathrm{t}=30^{\circ} \mathrm{C}$. From these $\mathrm{k}[\mathrm{S}]$ and $\mathrm{k}_{\text {cat }}[\mathrm{S}]$ values, $\mathrm{k}$ and $\mathrm{k}_{\text {cat }}$ found to be $0.24 \mathrm{~L} \mathrm{~mol}^{-1} \mathrm{~s}^{-1}$ and $2.13 \times 10^{5}$ respectively at $\mathrm{pH}=\sim 10.8$ and $\mathrm{t}=30^{\circ} \mathrm{C}$. The $\mathrm{k}$ value of $0.14 \mathrm{~L} \mathrm{~mol}^{-1} \mathrm{~s}^{-1}$ determined in the absence of hydroquinone compares favorably with the value of $0.24 \mathrm{~L}$ $\mathrm{mol}^{-1} \mathrm{~s}^{-1}$ under similar reaction conditions.

Table-3: The Selected Value of $\mathrm{k}_{\mathrm{H} 2 \mathrm{Q}}$ at $[\mathrm{S}]=2 \times 10^{-3} \mathrm{~mol} \mathrm{~L}^{-1}$ and $\mathrm{t}=30^{\circ} \mathrm{C}$

\begin{tabular}{c|c|c|c|c}
\hline $\begin{array}{c}{\left[\mathrm{O}_{2}\right],} \\
\mathrm{mg} / \mathrm{L}\end{array}$ & $\mathrm{pH}$ & {$[\mathrm{S}], \mathrm{mol} \mathrm{L}^{-1}$} & $\begin{array}{c}\text { Hydroquinone }], \\
\mathrm{mol} \mathrm{L}^{-1}\end{array}$ & $\mathrm{k}_{\mathrm{H} 2 \mathrm{Q}}, \mathrm{s}^{-1}$ \\
\hline 5.1 & 10.82 & $2 \times 10^{-3}$ & 0.0 & $2.87 \times 10^{-4}$ \\
\hline 5.03 & 10.83 & $2 \times 10^{-3}$ & $2 \times 10^{-6}$ & $1.65 \times 10^{-3}$ \\
\hline 4.84 & 10.84 & $2 \times 10^{-3}$ & $3 \times 10^{-6}$ & $1.92 \times 10^{-3}$ \\
\hline 4.81 & 10.83 & $2 \times 10^{-3}$ & $4 \times 10^{-6}$ & $2.24 \times 10^{-3}$ \\
\hline 4.86 & 10.74 & $2 \times 10^{-3}$ & $5 \times 10^{-6}$ & $2.25 \times 10^{-3}$ \\
\hline 4.53 & 10.78 & $2 \times 10^{-3}$ & $6 \times 10^{-6}$ & $2.85 \times 10^{-3}$ \\
\hline 4.51 & 10.83 & $2 \times 10^{-3}$ & $8 \times 10^{-6}$ & $4.02 \times 10^{-3}$ \\
\hline 4.66 & 10.78 & $2 \times 10^{-3}$ & $1 \times 10^{-5}$ & $4.78 \times 10^{-3}$ \\
\hline
\end{tabular}

\section{pH- Dependence}

Since in this reaction, multiple hydrogen sulfide species are involved, the $\mathrm{H}^{+}$ion dependence is an important parameter in deciding the nature of reactive species and the mechanism. The rate of reaction increases with an increase in $\mathrm{pH}$, i.e., decrease in $\left[\mathrm{H}^{+}\right]\left(\right.$Table-4). The order of reaction with respect to $\left[\mathrm{H}^{+}\right]$ was determined from the plot of $\log \mathrm{k}_{\mathrm{H} 2 \mathrm{Q}}$ versus $\log \left[\mathrm{H}^{+}\right]$and found to be $-0.35 \pm 0.04$. The nature of the effect of $\mathrm{pH}$ on $\mathrm{k}_{\mathrm{H} 2 \mathrm{Q}}$ is shown in Fig. -5 . 


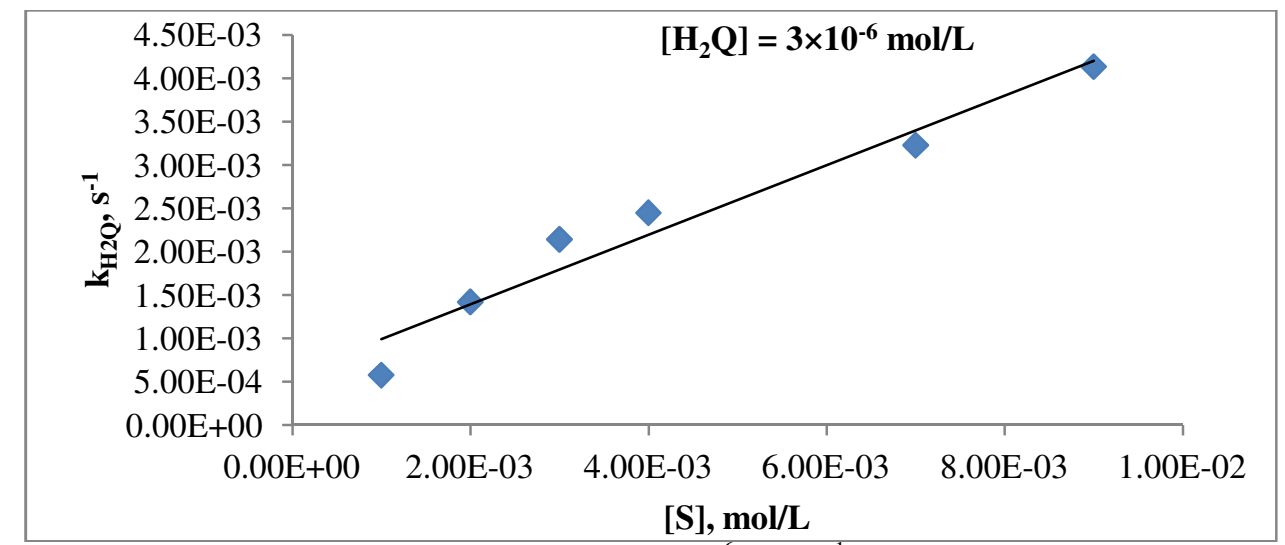

Fig.3-: The Plot of $\mathrm{k}_{\mathrm{H} 2 \mathrm{Q}}$ Versus $[\mathrm{S}]$ at $\left[\mathrm{H}_{2} \mathrm{Q}\right]=3 \times 10^{-6} \mathrm{~mol} \mathrm{~L}^{-1}, \mathrm{pH}=10.13-11.30$ and $\mathrm{t}=30^{\circ} \mathrm{C}$

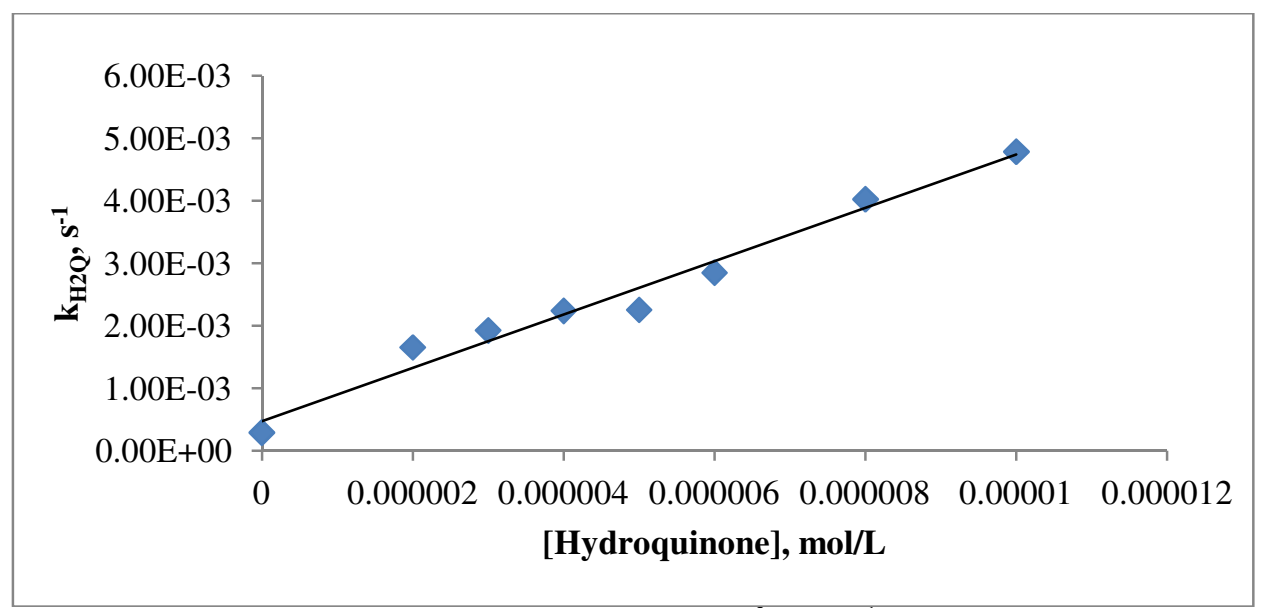

Fig.4-: The Plot of $\mathrm{k}_{\mathrm{H} 2 \mathrm{Q}}$ Versus $\left[\mathrm{H}_{2} \mathrm{Q}\right]$ at $[\mathrm{S}]=2 \times 10^{-3} \mathrm{~mol} \mathrm{~L}^{-1}, \mathrm{pH}=10.82$ and $\mathrm{t}=30^{\circ} \mathrm{C}$

In aqueous solution hydrogen sulfide exists as undissociated $\mathrm{H}_{2} \mathrm{~S}$ and $\mathrm{HS}^{-}$and $\mathrm{S}^{2-}$ ions governed by the equilibria(16-17) :

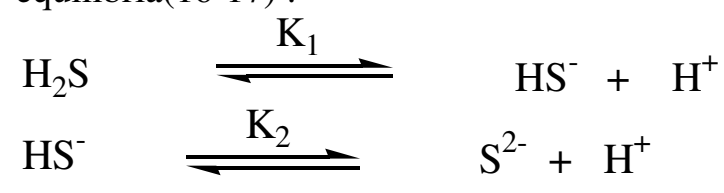

Where $\mathrm{K}_{1}$ and $\mathrm{K}_{2}$ are first and second dissociation constants of $\mathrm{H}_{2} \mathrm{~S}$. The kinetics in this work was investigated in the $\mathrm{pH}$ range $6.4-10.8$ and $\mathrm{K}_{1}=9.63 \times 10^{-8}$ and $\mathrm{K}_{2}=1.34 \times 10^{-13}$ were used. ${ }^{21}$ In the range of $\mathrm{pH}$ studied(7.89 - 10.18), the dominant form is $\mathrm{HS}^{-}$and it is more than $90 \%{ }^{22-23}$ and our calculations were in confirmative with the calculations of Chen and Morris ${ }^{22}$. A detailed analysis of $\left[\mathrm{H}^{+}\right]$- dependence of the reaction rate showed $\mathrm{HS}^{-}$to be not only dominant but also the reactive species.

\section{Effect of EDTA}

EDTA is known to complex the metal ions and inhibits the reactions in which the metal ions catalyzed the reaction by forming one or more complexes with the reactant. It is known to inhibit the aqueous $\mathrm{H}_{2} \mathrm{~S}^{18}$ and $\mathrm{SO}_{2}{ }^{24}$ autoxidation. In view of this, we examined its effect. Its addition led to strong inhibition as shown in Fig.-6.

\section{Mechanism of the Reaction}

The hydroquinone is well known to be oxidized into quinone and metals are known to play a catalytic role. ${ }^{25-26}$ The kinetics results of this study can be explained in terms of the following simple mechanism. 
RASĀYAN J. Chem.

Vol. 13 | No. 1 |112 - 120| January - March | 2020

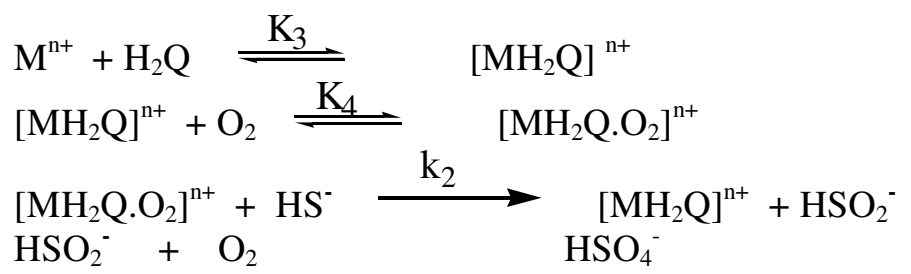

(slow) (20)

(fast) (21)

$\mathrm{K}_{3}$ and $\mathrm{K}_{4}$ are the equilibrium constants for the formation of intermediates $\left[\mathrm{MH}_{2} \mathrm{Q}\right]^{\mathrm{n}+}$ and $\left[\mathrm{MH}_{2} \mathrm{Q} \cdot \mathrm{O}_{2}\right]^{\mathrm{n}+}$ respectively and $\mathrm{k}_{2}$ is the rate constant for rate-determining step(20).

Table-4: The Selected Value of $\mathrm{k}_{\mathrm{H} 2 \mathrm{Q}}$ at $[\mathrm{S}]=2 \times 10^{-3} \mathrm{~mol} \mathrm{~L}^{-1},\left[\mathrm{H}_{2} \mathrm{Q}\right]=5 \times 10^{-6} \mathrm{~mol} \mathrm{~L}^{-1}$ and $\mathrm{t}=30^{\circ} \mathrm{C}$

\begin{tabular}{|c|c|c|c|c|c|}
\hline $\begin{array}{l}{\left[\mathrm{O}_{2}\right],} \\
\mathrm{mg} \mathrm{L}_{1}^{-}\end{array}$ & $\mathrm{pH}$ & $\mathrm{k}_{\mathrm{H} 2 \mathrm{Q}}, \mathrm{s}^{-1}$ & $\begin{array}{c}{\left[\mathrm{H}^{+}\right]^{2}+\mathrm{K}_{1}\left[\mathrm{H}^{+}\right]} \\
+\mathrm{K}_{1} \mathrm{~K}_{2}\end{array}$ & $\begin{array}{c}\mathrm{k}_{\mathrm{H} 2 \mathrm{Q}}\left\{\left[\mathrm{H}^{+}\right]^{2}+\mathrm{K}_{1}\left[\mathrm{H}^{+}\right]\right. \\
\left.+\mathrm{K}_{1} \mathrm{~K}_{2}\right\}\end{array}$ & $\begin{array}{c}\mathrm{k}_{\mathrm{H} 2 \mathrm{Q}}\left\{\left[\mathrm{H}^{+}\right]^{2}+\mathrm{K}_{1}\left[\mathrm{H}^{+}\right]+\right. \\
\left.\mathrm{K}_{1} \mathrm{~K}_{2}\right\} /[\mathrm{S}]\end{array}$ \\
\hline 4.80 & 10.18 & $1.05 \times 10^{-3}$ & $6.38 \times 10^{-18}$ & $6.67 \times 10^{-21}$ & $3.33 \times 10^{-18}$ \\
\hline 5.10 & 10.04 & $8.44 \times 10^{-4}$ & $8.80 \times 10^{-18}$ & $7.43 \times 10^{-21}$ & $3.71 \times 10^{-18}$ \\
\hline 4.81 & 9.91 & $1.55 \times 10^{-3}$ & $1.19 \times 10^{-17}$ & $1.84 \times 10^{-20}$ & $9.18 \times 10^{-18}$ \\
\hline 4.93 & 9.78 & $1.42 \times 10^{-3}$ & $1.60 \times 10^{-17}$ & $2.28 \times 10^{-20}$ & $1.14 \times 10^{-17}$ \\
\hline 4.84 & 9.71 & $4.75 \times 10^{-4}$ & $1.88 \times 10^{-17}$ & $8.95 \times 10^{-21}$ & $4.47 \times 10^{-18}$ \\
\hline 4.80 & 9.57 & $1.95 \times 10^{-4}$ & $2.60 \times 10^{-17}$ & $5.07 \times 10^{-21}$ & $2.54 \times 10^{-18}$ \\
\hline 4.80 & 9.50 & $1.41 \times 10^{-3}$ & $3.06 \times 10^{-17}$ & $4.30 \times 10^{-20}$ & $2.15 \times 10^{-17}$ \\
\hline 4.86 & 9.11 & $2.38 \times 10^{-4}$ & $7.54 \times 10^{-17}$ & $1.79 \times 10^{-20}$ & $8.95 \times 10^{-18}$ \\
\hline 4.91 & 8.72 & $1.00 \times 10^{-3}$ & $1.87 \times 10^{-16}$ & $1.87 \times 10^{-19}$ & $9.36 \times 10^{-17}$ \\
\hline 5.18 & 8.22 & $1.04 \times 10^{-4}$ & $6.17 \times 10^{-16}$ & $6.41 \times 10^{-20}$ & $3.21 \times 10^{-17}$ \\
\hline 4.83 & 8.19 & $3.29 \times 10^{-4}$ & $6.63 \times 10^{-16}$ & $2.18 \times 10^{-19}$ & $1.09 \times 10^{-16}$ \\
\hline 4.68 & 8.03 & $3.07 \times 10^{-4}$ & $8.92 \times 10^{-16}$ & $2.74 \times 10^{-19}$ & $1.37 \times 10^{-16}$ \\
\hline 5.60 & 7.89 & $2.03 \times 10^{-4}$ & $1.41 \times 10^{-15}$ & $2.86 \times 10^{-19}$ & $1.43 \times 10^{-16}$ \\
\hline 4.75 & 7.76 & $1.77 \times 10^{-4}$ & $1.98 \times 10^{-15}$ & $3.50 \times 10^{-19}$ & $1.75 \times 10^{-16}$ \\
\hline 4.85 & 7.56 & $9.29 \times 10^{-5}$ & $3.41 \times 10^{-15}$ & $3.17 \times 10^{-19}$ & $1.58 \times 10^{-16}$ \\
\hline 4.78 & 7.35 & $8.56 \times 10^{-5}$ & $6.30 \times 10^{-15}$ & $5.39 \times 10^{-19}$ & $2.69 \times 10^{-16}$ \\
\hline 4.71 & 7.27 & $1.36 \times 10^{-4}$ & $8.06 \times 10^{-15}$ & $1.10 \times 10^{-18}$ & $5.49 \times 10^{-16}$ \\
\hline 4.83 & 7.23 & $1.24 \times 10^{-4}$ & $9.14 \times 10^{-15}$ & $1.13 \times 10^{-18}$ & $5.66 \times 10^{-16}$ \\
\hline 5.08 & 7.19 & $6.64 \times 10^{-5}$ & $1.04 \times 10^{-14}$ & $6.90 \times 10^{-19}$ & $3.45 \times 10^{-16}$ \\
\hline 5.30 & 7.12 & $1.47 \times 10^{-4}$ & $1.31 \times 10^{-14}$ & $1.92 \times 10^{-18}$ & $9.62 \times 10^{-16}$ \\
\hline 5.26 & 7.03 & $1.00 \times 10^{-4}$ & $1.54 \times 10^{-14}$ & $1.55 \times 10^{-18}$ & $7.73 \times 10^{-16}$ \\
\hline 4.71 & 6.93 & $9.98 \times 10^{-5}$ & $2.51 \times 10^{-14}$ & $2.51 \times 10^{-18}$ & $1.25 \times 10^{-15}$ \\
\hline 4.91 & 6.58 & $3.88 \times 10^{-5}$ & $9.45 \times 10^{-14}$ & $3.66 \times 10^{-18}$ & $1.83 \times 10^{-15}$ \\
\hline 5.01 & 6.46 & $4.72 \times 10^{-5}$ & $1.54 \times 10^{-13}$ & $7.25 \times 10^{-18}$ & $3.63 \times 10^{-15}$ \\
\hline
\end{tabular}

This mechanism leads to rate law(22):

$-\mathrm{d}\left[\mathrm{O}_{2}\right] / \mathrm{dt}=\mathrm{k}_{2} \mathrm{~K}_{3} \mathrm{~K}_{4}\left[\mathrm{M}^{\mathrm{n}+}\right]\left[\mathrm{O}_{2}\right]\left[\mathrm{H}_{2} \mathrm{Q}\right]\left[\mathrm{HS}^{-}\right]$

From the equilibria(16-17) it can be shown that the equilibrium concentration of HS$^{-}$species is given by Eq.(23):

$\left[\mathrm{HS}^{-}\right]=\mathrm{K}_{1}[\mathrm{~S}]\left[\mathrm{H}^{+}\right] /\left(\left[\mathrm{H}^{+}\right]^{2}+\mathrm{K}_{1}\left[\mathrm{H}^{+}\right]+\mathrm{K}_{1} \mathrm{~K}_{2}\right)$

On substituting the value of [HS'] in Eq.(22) we get the complete rate law(24):

OXIDATION OF HYDROGEN SULFIDE 
$-\mathrm{d}\left[\mathrm{O}_{2}\right] / \mathrm{dt}=\mathrm{k}_{2} \mathrm{~K}_{1} \mathrm{~K}_{3} \mathrm{~K}_{4}\left[\mathrm{M}^{\mathrm{n}+}\right]\left[\mathrm{O}_{2}\right]\left[\mathrm{H}_{2} \mathrm{Q}\right][\mathrm{S}]\left[\mathrm{H}^{+}\right] /\left(\left[\mathrm{H}^{+}\right]^{2}+\mathrm{K}_{1}\left[\mathrm{H}^{+}\right]+\mathrm{K}_{1} \mathrm{~K}_{2}\right)$ or $\mathrm{k}_{\mathrm{H} 2 \mathrm{Q}}=\mathrm{k}_{2} \mathrm{~K}_{1} \mathrm{~K}_{3} \mathrm{~K}_{4}\left[\mathrm{M}^{\mathrm{n}+}\right]\left[\mathrm{H}_{2} \mathrm{Q}\right][\mathrm{S}]\left[\mathrm{H}^{+}\right] /\left(\left[\mathrm{H}^{+}\right]^{2}+\mathrm{K}_{1}\left[\mathrm{H}^{+}\right]+\mathrm{K}_{1} \mathrm{~K}_{2}\right)$ $\mathrm{k}_{\mathrm{H} 2 \mathrm{Q}}\left(\left[\mathrm{H}^{+}\right]^{2}+\mathrm{K}_{1}\left[\mathrm{H}^{+}\right]+\mathrm{K}_{1} \mathrm{~K}_{2}\right) /[\mathrm{S}]=\mathrm{k}_{2} \mathrm{~K}_{1} \mathrm{~K}_{3} \mathrm{~K}_{4}\left[\mathrm{M}^{\mathrm{n}+}\right]\left[\mathrm{H}_{2} \mathrm{Q}\right]\left[\mathrm{H}^{+}\right]$

As required by Eq. (26) the plot of $\mathrm{k}_{\mathrm{H} 2 \mathrm{Q}}\left(\left[\mathrm{H}^{+}\right]^{2}+\mathrm{K}_{1}\left[\mathrm{H}^{+}\right]+\mathrm{K}_{1} \mathrm{~K}_{2}\right) /[\mathrm{S}]$ versus $\left[\mathrm{H}^{+}\right]$is a straight line passing through origin(Fig.-7). The slope of this plot is equal to $\mathrm{k}_{2} \mathrm{~K}_{1} \mathrm{~K}_{3} \mathrm{~K}_{4}\left[\mathrm{M}^{\mathrm{nt}}\right]\left[\mathrm{H}_{2} \mathrm{Q}\right]$. By dividing the value of slope by $\left[\mathrm{H}_{2} \mathrm{Q}\right]$ the value of $\mathrm{k}_{2} \mathrm{~K}_{1} \mathrm{~K}_{3} \mathrm{~K}_{4}\left[\mathrm{M}^{\mathrm{n}+}\right]=1.86 \times 10^{-3}$ at $30^{\circ} \mathrm{C}$.

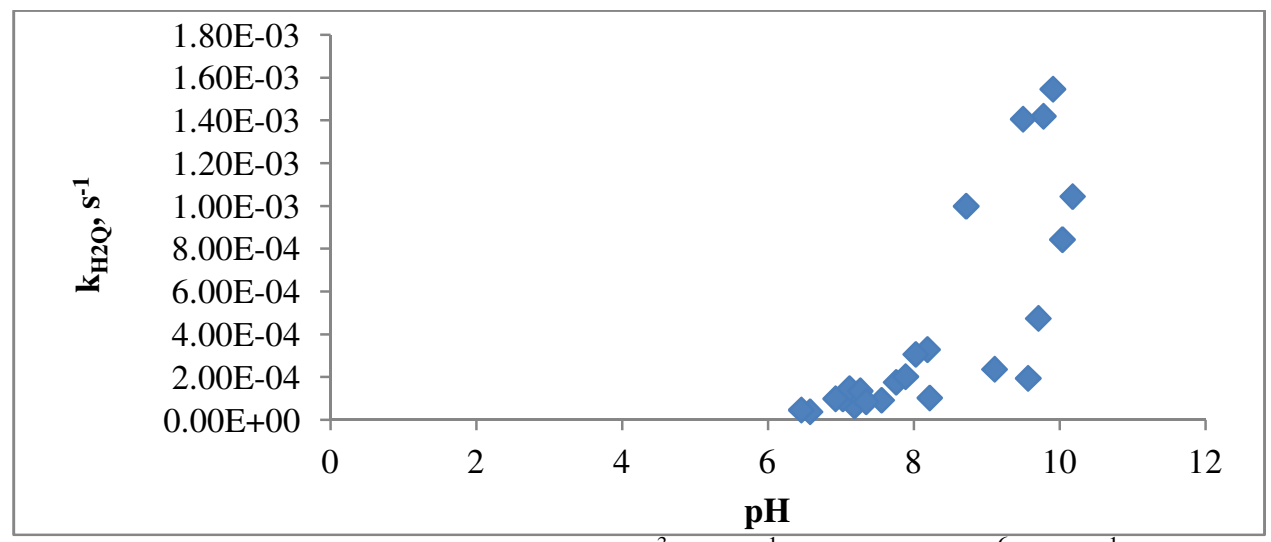

Fig.5-: The Plot of $\mathrm{k}_{\mathrm{H} 2 \mathrm{Q}}$ Versus $\mathrm{pH}$ at $[\mathrm{S}]=2 \times 10^{-3} \mathrm{~mol} \mathrm{~L}^{-1},\left[\mathrm{H}_{2} \mathrm{Q}\right]=5 \times 10^{-6} \mathrm{~mol} \mathrm{~L}^{-1}$ and $\mathrm{t}=30^{\circ} \mathrm{C}$

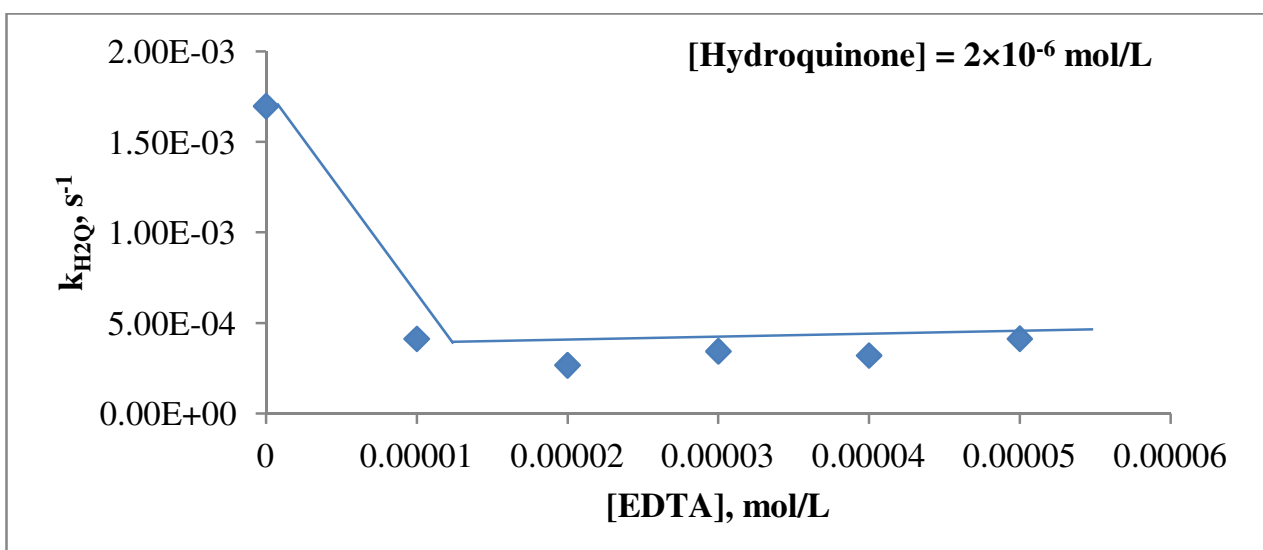

Fig.6-: The Plot of $\mathrm{k}_{\mathrm{H} 2 \mathrm{Q}}$ Versus [EDTA] at $[\mathrm{S}]=2 \times 10^{-3} \mathrm{~mol} \mathrm{~L}^{-1},\left[\mathrm{H}_{2} \mathrm{Q}\right]=2 \times 10^{-6} \mathrm{~mol} \mathrm{~L}^{-1}, \mathrm{pH}=10.68$ and $\mathrm{t}=30^{\circ} \mathrm{C}$

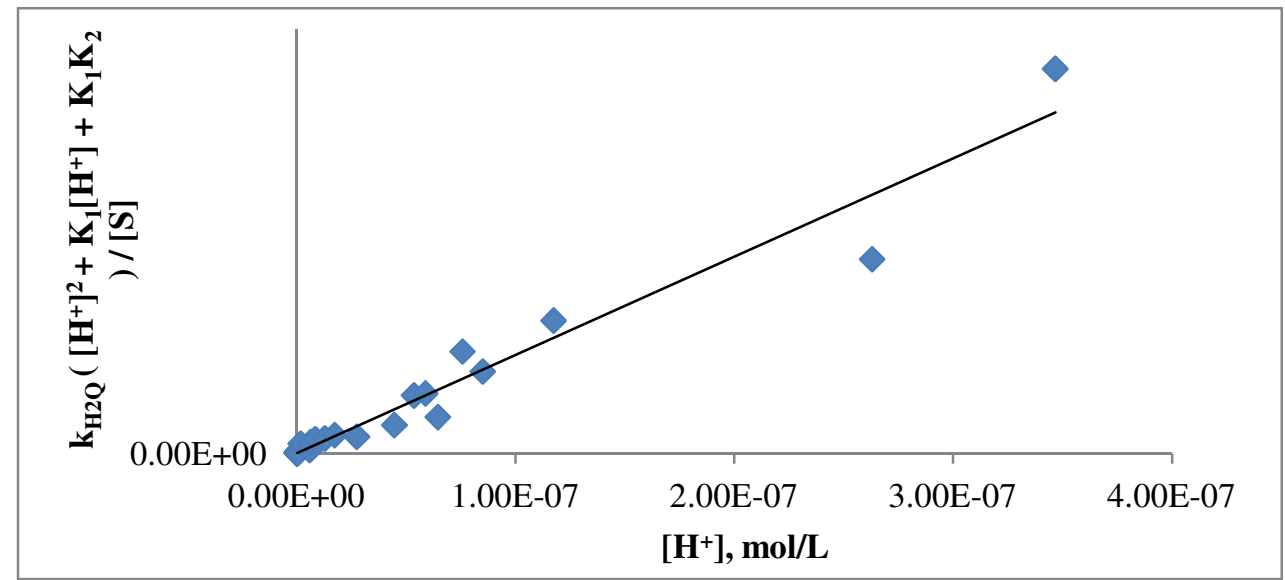

Fig.7-: The Plot of $\mathrm{k}_{\mathrm{H} 2 \mathrm{Q}}\left(\left[\mathrm{H}^{+}\right]^{2}+\mathrm{K}_{1}\left[\mathrm{H}^{+}\right]+\mathrm{K}_{1} \mathrm{~K}_{2}\right) /[\mathrm{S}]$ Versus $\left[\mathrm{H}^{+}\right]$at $[\mathrm{S}]=2 \times 10^{-3} \mathrm{~mol} \mathrm{~L}^{-1},\left[\mathrm{H}_{2} \mathrm{Q}\right]=2 \times 10^{-6} \mathrm{~mol} \mathrm{~L}^{-1}$ and $\mathrm{t}=30^{\circ} \mathrm{C}$ 
The mechanism (18-21) is not unique and several alternative mechanisms that will lead to the same rate law as observed experimentally. It is interesting to point out that the transition metal catalysis and the formation of the ternary complex, metal-reductant-oxidant, have been proposed earlier. ${ }^{27-29}$

This work shows hydroquinone to be a strong catalyst for the oxidation of $\mathrm{H}_{2} \mathrm{~S}$ by $\mathrm{O}_{2}$ and therefore it will catalyze the oxidation of aqueous $\mathrm{H}_{2} \mathrm{~S}$ into $\mathrm{H}_{2} \mathrm{SO}_{4}$ and contribute the acidification of atmospheric water.

\section{CONCLUSION}

The oxidation of aqueous $\mathrm{H}_{2} \mathrm{~S}$ by oxygen is strongly catalyzed by hydroquinone. It obeys the rate law: $\mathrm{d}\left[\mathrm{O}_{2}\right] / \mathrm{dt}=\mathrm{k}_{2} \mathrm{~K}_{1} \mathrm{~K}_{3} \mathrm{~K}_{4}\left[\mathrm{M}^{\mathrm{n}+}\right]\left[\mathrm{O}_{2}\right]\left[\mathrm{H}_{2} \mathrm{Q}\right][\mathrm{S}]\left[\mathrm{H}^{+}\right] /\left(\left[\mathrm{H}^{+}\right]^{2}+\mathrm{K}_{1}\left[\mathrm{H}^{+}\right]+\mathrm{K}_{1} \mathrm{~K}_{2}\right)$. The addition of EDTA strongly inhibited the rate of oxidation. Hydroquinone which is a trace atmospheric constituent will strongly catalyze the oxidation of $\mathrm{H}_{2} \mathrm{~S}$ by oxygen in atmospheric water and contributes to acid rain.

\section{REFERENCES}

1. U.S. Department of Health and Human Services, Hazardous Substances Data Bank (HSDB online database), National Library of Medicine Toxnet System: Record No. 123-31-9, Hydroquinone, in http://www.toxnet.nlm.nih.gov.

2. U.S. Environmental Protection Agency, Health and Environmental Effects Document for pHydroquinone, ECAO-CIN-G015. Environmental Criteria and Assessment Office, Office of Health and Environmental Assessment, Office of Research and Development, Cincinnati, OH, (1987).

3. S. Patai, The Chemistry of the Quinonoid Compounds, John Wiley \& Sons, New York, (1974).

4. S. Patai and Z. Rappoport, The Chemistry of Quinonoid Compounds, Vol II, John Wiley \& Sons, New York, (1988).

5. R.H. Thomson, Naturally Occurring Quinones, Academic Press, London and New York, (1971).

6. R.H. Thomson, Naturally Occurring Quinones, III, Recent advances, Chapman \& Hall, London, (1987).

7. J.P. Brown, Mutation Research, 75, 243(1980), DOI:10.1016/0165-1110(80)90029-9

8. M.T. Smith, C.G. Evans, H. Thor, S. Orrenius, 1985, Quinone -induced oxidative injury to cells and tissues, in: H. Sies (Eds.), Oxidative Stress, Academic Press, London, pp.91-113.

9. H. Nohl, W. Jordon and R.J. Youngman, Advances in Free Radical Biology \& Medicine, 2, 211(1986), DOI:10.1016/S8755-9668(86)80030-8

10. A. Brunmark and E. Cadenas, Free Radical Biology and Medicine,7, 435(1989), DOI: 10.1016/08915849(89)90126-3

11. T.J. Monkas, R.P. Hanzlik, G.M. Cohen, D. Ross and D.G. Graham, Toxicology and Applied Pharmacology, 112, 2(1992), DOI: 10.1016/0041-008X(92)90273-U

12. R. L. Willson, Free Radical Research Communications, 8, 201(1990), DOI: $10.3109 / 10715769009053354$

13. P. Wardman, Free Radical Research Communications, 8, 219(1990), DOI: 10.3109/10715769009053355

14. B. Bandy, Ph. D. Thesis, Simon Fraser University, British Columbia, Canada (1994).

15. D.M. Miller, G.R. Buettner and S.D. Aust, Free Radical Biology and Medicine, 8, 95 (1990), DOI: 10.1016/0891-5849(90)90148-C

16. M.R. Hoffmann and B. C. Lim, Environmental Science \& Technology, 13,1406(1979), DOI: 10.1021/es60159a014

17. J.Z. Zhang and F.J. Millero, 1994, The kinetics of oxidation of hydrogen sulfide in natural waters, in: C.N. Alpers and D.W. Blowes (Eds.), Environmental Geochemisry of Sulfide Oxidation, Am. Chem. Soc., Washington DC, pp. 393-409.

18. O. Weres and L. Tsao, Reaction of hydrogen sulfide with oxygen in the presence of sulfite, Earth Sciences Division, Lawrence Berkeley Laboratory, University of California, Berkeley, p. 4-30 (1983).

19. P.K. Mudgal, S.P. Bansal and K.S. Gupta, Atmospheric Environment, 41, 4097(2007), DOI: 10.1016/j.atmosenv.2007.01.036

20. V. K. Meena, Y. Dhayal, D.S. Rathore, C.P.S. Chandel and K.S. Gupta, International Journal of Chemical Kinetics, 49,221(2017), DOI: 10.1002/kin.21069 
RASĀYAN J. Chem.

Vol. 13 | No. 1 |112 - 120| January - March | 2020

21. W. Sun, S. Nesic, D. Young and R.C. Woollam, Industrial \& Engineering Chemistry Research, 47, 1738(2008), DOI: 10.1021/ie070750i

22. K.Y. Chen and J.C. Morris, Environmental Science \& Technology, 6, 529(1972), DOI: 10.1021/es60065a008

23. F.J. Millero, S. Hubinger, M. Fernandez and S. Garnett, Environmental Science \& Technology, 21, 439(1987), DOI: 10.1021/es00159a003

24. D.S.N. Prasad, A. Rani and K.S. Gupta, Environmental Science \& Technology, 26, 1361(1992), DOI:10.1021/es00031a013

25. K.Y. Chen and J.C. Morris, Journal of the Sanitary Engineering Division, 98, 215(1972)

26. F.J. Millero, Marine Chemistry, 18, 121(1986), DOI: 10.1016/0304-4203(86)90003-4

27. Sushma, R.D. Kaushik, M.M. Tiwari, M. Chawla and J. Singh, Rasayan Journal of Chemistry, 12, 1203(2019), DOI:10.31788/RJC.2019.1235348

28. K. Rawat, J. Singh, R.D. Kaushik and N. Khandelwal, Rasayan Journal of Chemistry, 11, 1328(2018), DOI:10.31788/RJC.2018.1133095

29. R.D. Kaushik, J. Singh, R. Agarwal, P. Rathi and E. Kumari, Rasayan Journal of Chemistry, 10, 461(2017), DOI:10.7324/RJC.2017.1021690

[RJC-5612/2019] 